\title{
DAMPAK MANAJEMEN PENGELOLAAN SAMPAH TERHADAP MASYARAKAT DAN LINGKUNGAN DI TPAS NAMO BINTANG DELISERDANG
}

\author{
Elida F. S. Simanjorang \\ Dosen Tetap Sekolah Tinggi Ilmu Ekonomi (STIE) Labuhanbatu
}

\begin{abstract}
ABSTRAK
Tujuan penelitian ini adalah untuk memperoleh informasi dan data-data tentang berdirinya Tempat Pembuangan Akhir Sampah (TPAS) Namo Bintang di Kabupaten Deliserdang, serta dampaknya kepada masyarakat dan lingkungan sesudah berdirinya TPAS tersebut. Metode yang digunakan dalam penelitian ini adalah pendekatan kualitatif. dengan mengajukan pertanyaan-pertanyaan (tanya jawab) kepada Responden dan Informan. Responden dalam penelitian ini adalah petani, pemulung, dan petani sekaligus pemulung yang berjumlah 10 orang. Sedangkan Informan yang ditentukan dalam penelitian ini adalah kepala lingkungan dan seseorang yang sudah lama tinggal di situ. Jumlah informan ada sebanyak dua (2) orang. Dari hasil penelitian dapat disimpulkan bahwa pengaruh dari manajemen pengelolaan TPAS terhadap masyarakat dan lingkungan cenderung ke arah yang lebih negatif. Hal ini antara lain karena dampak berdirinya TPAS di Namo Bintang ini menimbulkan gangguan pada kesehatan, pendidikan, dan pendapatan masyarakat sekitar. Dengan pendapatan yang rendah, masyarakat kesulitan untuk memenuhi kebutuhan kehidupan mereka sehari-hari. Pendapatan yang rendah juga menyebabkan peluang yang sangat kecil untuk membiayai pendidikan anak-anak mereka ke jenjang pendidikan yang lebih tinggi. Sedangkan lingkungan yang tidak sehat akan berdampak pada kesehatan masyarakat. Selain dari pada itu, lingkungan yang sehat juga sangat diperlukan bagi pendidikan anak, sebab anak yang kurang sehat akan terganggu proses belajarnya. Bila banyak hal ini terus dibiarkan, maka akan dapat menimbulkan masalah sosial yang baru lagi. Sedangkan saran yang dapat diberikan antara lain ialah agar pemerintah setempat lebih memperhatikan masyarakat yang ada di sekitar TPAS khususnya di desa Namo Bintang terutama menyangkut kesehatan. Selain itu pemerintah juga harus lebih memperhatikan kesejahteraan masyarakat desa Namo Bintang dan penduduk yang ada di sekitarnya terutama dalam pengadaan sarana umum seperti air bersih dan listrik.
\end{abstract}

Kata kunci : Manajemen Pengelolaan Sampah, Masyarakat, Lingkungan

\section{Pendahuluan}

Permasalahan sampah di indonesia selama ini telah menjadi masalah yang serius yang belum dapat diselesaikan dengan baik oleh pemerintah kab/kota permasalahan tersebut disebabkan oleh keterbatasan pendanaan untuk peneyediaan insfratruktur juga juga rendahnya tingkat pelayanan pesampahan terhadap masyarakat hampir semua tempat pembuangan.

Akhir Sampah (TPAS) tidak dapat lagi menampung sampah yang dihasilkan oleh masyarakat, sehingga sampah menumpuk dan menimbulkan bau yang tidak sedap yang dapat menimbulkan berbagai masalah di perkotaan seperti penyakit, banjir, dll. 
Sampahadalahsisahasil kegiatan manusia yang sudah tak terpakai. Sampah/limbah dibedakan menjadi 3 bentuk, yaitu limbah padat, limbah cair, dan limbah gas. Di antaranya yang paling sering banyak adalah limbah padat yang berupa sampah, yang hampir di setiap tempat dapat dijumpai. Sampah adalah konsekuensi dari adanya kegiatan manusia yang menghasilkan buangan (Dwiyatmo, 2007).

Sampah pada dasarnya merupakan suatu bahan yang terbuang atau dibuang dari suatu sumber hasil aktivitas manusia maupun proses-proses alam yang tidak mempunyai nilai ekonomi, bahkan dapat mempunyai nilai ekonomi yang negatif karena dalam penanganannya baik untuk membuang atau membersihkannya memerlukan biaya yang cukup besar.

Sampah merupakan sisa benda atau barang manusia yang telah digunakan dan merupakan konsekuensi dari adanya aktivitas manusia. Kehidupan manusia tidak pernah lepas dari masalah sampah, fakta menunjukkan bahwa potensi sampah terus meningkat seiring dengan pertambahan jumlah penduduk. Pada umumnya, sebagian besar sampah yang dihasilkan di tempat pembuangan akhir sampah (TPAS) merupakan sampah organik yang mudah terurai dan sampah anorganik. Sampah organik adalah sampah yang terbentuk dari zat-zat organik dan dapat diuraikan. Contoh sampah ini adalah daun, sisa sayuran, dll. Sedangkan sampah anorganik adalah sampah yang berasal dari benda-benda yang tidak dapat diuraikan, contohnya:

plastik, kaleng, dll.

Jumlah atau volume sampah sebanding dengan tingkat konsumsi kita terhadap barang atau material yang kita gunakan sehari-hari. Demikian juga dengan jenis sampah, sangat tergantung dari jenis material yang kita konsumsi. Oleh karena itu manajemen pengelolaan sampah tidak bisa lepas juga dari 'manajemen pengelolaan' gaya hidup masyarakat.

Berdasarkan jenisnya, sampah perkotaan di Indonesia dapat dibedakan menjadi sampah organik (biasa disebut sebagai sampah basah), yaitu buangan sisa makanan misalnya daging, buah, sayuran dan sebagainya. Sampah anorganik (sampah kering), yaitu sisa material sintetis misalnya plastik, kertas, logam, kaca, keramik dan sebagainya; terakhir, buangan Bahan Berbahaya dan Beracun (B3), yaitu buangan yang memiliki karakteristik mudah terbakar, korosif, reaktif, dan beracun. B3 kebanyakan merupakan buangan dari industri, namun ada juga sebagian kecil merupakan buangan dari aktifitas masyarakat kota atau desa misalnya baterai, aki, disinfektan dan sebagainya.

Komposisi sampah mencakup persentase dari komponen pembentuk sampah yang secara fisik dapat dibedakan antara sampah organik, kertas, plastik, logam dan lain-lain. Komposisi sampah ini dapat digunakan sebagai bahan pertimbangan untuk menentukan pilihan kelayakan pengolahan sampah khususnya daur ulang dan pembuatan kompos serta kemungkinan penggunaan gas landfill sebagai energi elternatif.

Masalah sampah merupakan fenomena sosial yang perlu mendapat perhatian dari semua pihak karena setiap manusia pasti memproduksi sampah, disisi lain masyarakat tidak ingin berdekatan dengan sampah. Sampah merupakan bagian yang tidak dapat terpisahkan dari kehidupan masyarakat, terutama di daerah perkotaan. Sampah apabila tidak ditangani secara baik dan benar dari sumber sampah, maka akan menimbulkan masalah terhadap kesehatan, sosial, ekonomi dan keindahan (Nugroho, 2009).

Sampah sebagai hasil buangan dari kegiatan produksi dan konsumsi manusia baik dalam bentuk padat, cair, maupun gas merupakan sumber pencemaran lingkungan hidup yang dapat menyebabkan dis-ekonomi (kemerosotan ekonomi) kawasan perkotaan. Permasalahan dalam penanganan sampah terjadi karena ketidakseimbangan antara produksi dengan kemampuan dalam pengelolaannya, volume sampah terus meningkat sejalan dengan pertambahan penduduk, perubahan kualitas hidup dan dinamika kegiatan masyarakat. Sampah 
yang tidak dikelola inilah penyebab terjadinya gangguan kesehatan karena menjadi sarang penyakit, menjijikan dan menimbulkan bau yang tidak sedap, banjir, pencemaran tanah, air dan berkurangnya nilai kebersihan dan keindahan lingkungan (Nugraha, 2007).

Ditinjau dari segi ekonomi usaha pengomposan sampah kota khususnya sampah organik menjadi pupuk kompos memiliki nilai ekonomis, disamping pupuk kompos dimanfaatkan untuk tanaman organik yang sudah menjadi kebutuhan manusia saat ini. Disamping itu dengan menghasilkan pupuk kompos dari sampah organik akan mengurangi kerusakan lingkungan akibat penggunaan pupuk kimia yang selama ini banyak digunakan petani. Saat ini penanganan sampah organik menjadi pupuk kompos beragam cara dilakukan oleh masyarakat. Pengolahan sampah organik diantaranya adalah pengolahan sampah organik menjadi pupuk kompos secara konvensional (windrow), dan pengolahan sampah organik menggunakan berbagai metode baik secara aerobik maupun anerobik (Santoso, 2009).

Secara umum manajemen pengelolaan sampah di perkotaan dilakukan melalui tiga tahapan kegiatan, yakni : pengumpulan, pengangkutan dan pembuangan akhir atau pengolahan akhir. Tahapan kegiatan tersebut merupakan suatu sistem, sehingga masingmasing tahapan dapat disebut sebagai sub-sistem. Masalahnya adalah tiap perkotaan mempunyai cara sendiri untuk mengelola sampah, dan apakah sistem tersebut tidak menimbulkan dampak terhadap kondisi lingkungan setempat baik secara fisik maupun sosial. Sebagai bagian dari sistem pengelolaan sampah (sub-sistem) TPS memegang peranan penting dalam pengelolaan sampah. Keberadaan TPS menyebar hampir diseluruh Bagian Wilayah Kota (BWK) sehingga memudahkan bagi petugas pengelola sampah untuk sementara waktu menampung produksi sampah kota. Produksi sampah seluruh kota ditampung di berbagai Tempat Pembuangan Sampah Sementara (TPS) dan Transfer Depo (TD), yang nantinya akan diangkut kemudian dikumpulkan dan ditampung di Tempat Pembuangan Akhir Sampah (TPAS) (Aji, 2008).

Menurut perkiraan dari Badan Pusat Statistik (PBS) jumlah sampah pada tahun 2020 di 384 kota di Indonesia mencapai 80.235,87 ton tiap hari. Dari sampah yang dihasilkan tersebut diperkirakan sebesar 4,2\% akan diangkut ke Tempat Pembuangan Akhir (TPA), sebanyak 37,6\% dibakar, dibuang ke sungai sebesar 4,9\% dan tidak tertangani sekitar 53,3\%. Dari sekitar 53,3\% sampah yang tidak ditangani dibuang dengan cara tidak saniter dan menurut perkiraan National Urban Development Strategy (NUDS) tahun 2003 rata rata volume sampah yang dihasilkan per orang sekitar 0,5-0,6 kg/hari (Sukir, 2010).

Misalnya saja, seluruh sampah dari kota harus dibuang di Tempat Pembuangan Akhir (TPA) yang berada jauah dari kota. Dapat dibayangkan berapa ongkos yang harus dikeluarkan untuk ini. Belum lagi, sampah yang dibuang masih tercampur antara sampah basah dan sampah kering. Padahal, dengan mengelola sampah besar di tingkat lingkungan terkecil, seperti RT atau RW, dengan membuatnya menjadi kompos maka paling tidak volume sampah dapat diturunkan atau dikurangi. Masalah yang sering muncul dalam penanganan sampah kota adalah masalah biaya operasional yang tinggi dan semakin sulitnya ruang yang pantas untuk pembuangan. Sebagai akibat biaya operasional yang tinggi, kebanyakan kota-kota di Indonesia hanya mampu mengumpulkan dan membuang +/- 60\% dari seluruh produksi sampahnya, dari $60 \%$ ini sebagian besar ditangani dan dibuang dengan cara yang tidak saniter, boros dan mencemari.

Sampah dan pengelolaannya kini menjadi masalah yang kian mendesak di kota di Indonesia, sebab apabila tidak dilakukan penanganan yang baik akan mengakibatkan terjadinya perubahan keseimbangan lingkungan yang merugikan atau tidak diharapkan sehingga dapat mencemari lingkungan baik terhadap tanah, air dan udara. Oleh karena itu untuk mengatasi masalah pencemaran tersebut diperlukan penanganan dan pengendalian terhadap sampah. Penanganan dan pengendalian akan menjadi semakin kompleks dan rumit dengan semakin 
kompleksnya jenis maupun komposisi dari sampah sejalan dengan semakin majunya kebudayaan.

Berbagai masalah sosial ekonomi pengelolaan sampah (Yanti, 2012) adalah :

1. Pengelolaan sampah yang kurang baik akan membentuk lingkungan yang

kurang menyenangkan bagi masyarakat, seperti bau yang tidak sedap dan pemandangan

yang buruk karena sampah bertebaran dimana-mana.

2. Memberikan dampak negatif terhadap kepariwisataan.

3. Pengelolaan sampah yang tidak memadai menyebabkan rendahnya tingkat kesehatan masyarakat.

4. Pembuangan sampah padat ke badan air dapat menyebabkan banjir dan akan memberikan dampak bagi fasilitas pelayanan umum seperti jalan, jembatan, drainase, dan lain-lain.

5. Infrastruktur lain dapat juga dipengaruhi oleh pengelolaan sampah yang tidak memadai, seperti tingginya

biayayangdiperlukanuntuk

pengolahan air. Jika sarana penampungan sampah kurang atau tidak efisien, orang akan cenderung membuang sampahnya di jalan. Hal ini mengakibatkan jalan perlu lebih sering dibersihkan dan diperbaiki.

Di samping itu, dari manajemen pengelolaan persampahan yang sedang berjalan sampai saat ini, ternyata masih belum mampu menangani persampahan, karena ada beberapa masalah yang timbul dalam manajemen penanganan sampah saat ini, yaitu :

1. Pengumpulan sampah tidak efisien karena mulai dari sumber sampah (hulu) sampai ke TPA (hilir), sampah belum dipilah sehingga kalaupun akan diterapkan teknologi lanjutan berupa komposting maupun daur ulang perlu tenaga untuk pemilahan menurut jenisnya sesuai yang dibutuhkan, dan hal ini akan memerlukan dana maupun menyita waktu.

2. Pembuangan akhir ke TPAS dapat menimbulkan masalah, diantaranya :

Perlu lahan yang besar untuk TPAS sehingga hanya sesuai bagi kota yang masih mempunyai banyak lahan yang tidak terpakai. Hal ini akan timbul berbagai masalah sosial dan lingkungan, diantaranya :

Dapat menjadi lahan yang subur bagi pembiakan jenis-jenis bakteri serta bibit penyakit lain

Dapat menimbulkan bau tidak sedap

Dapatmenguranginilai

estetikadankeindahan

lingkungan yang bisa menimbulkan efek negatif citra lingkungan

Biaya operasional sangat tinggi bagi pengumpulan,

pengangkutan dan pengolahan lebih lanjut.

3. Belum maksimalnya usaha pemasaran bagi kompos yang dihasilkan dari proses pengomposan sampah kota

4. Belum maksimalnya upaya sistem daur ulang menjadi barang-barang yang bernilai ekonomi tinggi

5. Sulitnya mendapatkan tambahan biaya bagi peningkatan kesejahteraan

petugas yang terlibat dalam penanganan sampah. Hal ini tentu akan berakibat pada kegairahan kerja yang rendah dari para pengelola sampah. Keberadaan lokasi Tempat Pembuangan Akhir Sampah (TPAS) seharusnya tidak akan mempengaruhi pola kehidupan masyarakat sekitarnya baik secara fisik ataupun sosial, juga tidak 
mempengaruhi kondisi ekologis lingkungan disekitar lokasi TPAS seperti adanya pencemaran atau kerusakan lingkungan. Masyarakat di lokasi sekitar TPAS sudah sepantasnya mendapatkan hak yang sama atas lingkungan hidup yang baik dan sehat, juga hak atas informasi lingkungan hidup yang berkaitan dengan peran dalam pengelolaan lingkungan hidup, serta hak untuk berperan dalam rangka pengelolaan lingkungan hidup sesuai dengan peraturan perundang-undangan yang berlaku. Sebaliknya keberadaan TPAS diharapkan akan memberikan nilai tambah bagi masyarakat sekitar misalnya seperti nilai pendapatan atau ekonomi keluarga dari hasil pengolahan sampah.

Sebagai contoh Kota Medan merupakan kota inti di Sumatera Utara mempunyai beban volume sampah yang diproduksi penduduk sebesar $5.710 \mathrm{~m} 3 /$ hari. Dari produksi sampah tersebut yang mampu diangkut oleh Dinas Kebersihan kota Medan baru 68\%, sedangkan 32\% belum terangkut. Jumlah penduduk kota medan 2.567.288 jiwa yang menghasilkan timbunan sampah setiap harinya sebesar $\pm 887,75$ ton (Pemerintah Kota Medan, 2010),

sehingga memerlukan pengelolaan sampah yang baik. Kota Medan yang mempunyai 2 (dua) lokasi TPAS yaitu TPAS Terjun dan TPAS Namo Bintang yang setiap harinya melayani sampah kota Medan. Tempat pembuangan Akhir Sampah Kotamadya Medan atau lazimnya disingkat dengan TPAS di desa Namo Bintang Kecamatan Pancur Batu Kabupaten Deli Serdang, terletak di sebelah Utara desa Namo Bintang dan mempunyai luas areal sekitar 25 hektare. Jarak dari pemukiman ke areal TPAS ini sekitar 1,5 km dan terletak di pinggir jalan arah jalan besar Pancur Batu. Sedangkan jarak dari Kotamadya Medan ke TPAS ini berkisar $17 \mathrm{~km}$.

Untuk itu judul yang ditetapkan dalam penelitian ini adalah Dampak Pengelolaan Sampah terhadap Sosial Ekonomi Masyarakat dan Lingkungan di TPAS Namo Bintang Deliserdang.

\section{Tujuan Penelitian}

Tujuan penelitian ini adalah untuk memperoleh informasi, data-data tentang berdirinya TPAS Namo Bintang Kabupaten Deliserdang, serta dampaknya kepada masyarakat dan lingkungan sesudah berdirinya TPAS.

\section{Landasan Teoritis}

\section{\& Sampah Pengerti}

Berdasarkan atas Surat Keputusan

Menteri Pekerjaan Umum No. 184/KPTS/1990 tentang pengesahan 18 konsep SNI bidang PU, pengertian sampah adalah sebagai berikut :

a. Sampah adalah limbah yang bersifat padat terdiri dari zat organik dan anorganik yang tidak berguna lagi dan harus dikelola

agartidakmembahayakan

lingkungan dan melindungi investasi dari kerusakan.

b. Sampah kota adalah sampah yang timbul di perkotaan (tidak

termasuk sampah yang berbahaya dan beracun).

Menurut Kodoatie (2003), menyebutkan bahwa sampah adalah limbah atau buangan yang bersifat padat atau setengah padat yang merupakan hasil sampingan dari kegiatan perkotaan atau siklus kehidupan manusia, hewan bahkan tumbuh-tumbuhan.

Menurut Standar Nasional Indonesia (SNI) Nomor T-13-1990, yang dimaksud dengan sampah adalah limbah yang bersifat padat terdiri dari zat organik dan anorganik yang dianggap tidak berguna lagi dan harus dikelola agar tidak membahayakan lingkungan dan melindungi investasi bangunan. 
Dari pendapat beberapa ahli tersebut dapat disimpulkan bahwa sampah adalah benda atau sebagian dari sesuatu yang tidak dipakai atau sesuatu yang harus dibuang, dan umumnya bersifat padat yang dapat mencemari lingkungan dan tidak/belum bersifat ekonomis ${ }_{2}$ yang bersifat zat organik dan zat anorganik yang dianggap tidak berguna lagi dan harus dikelola agar tidak membahayakan lingkungan.

\section{Jenis-jenis Sampah}

Menurut Daniel (2009) terdapat tiga jenis sampah, di antaranya:

1 Sampah organik: sampah yang terdiri dari bahan-bahan yang bisa terurai secara alamiah/biologis, seperti sisa makanan dan guguran daun. Sampah jenis ini juga biasa disebut sampah basah.

2 Sampah anorganik: sampah yang terdiri dari bahan-bahan yang sulit terurai secara biologis. Proses penghancurannya membutuhkan penanganan lebih lanjut di tempat khusus, misalnya plastik, kalengdan styrofoam. Sampah jenis ini juga biasa disebut sampah kering.

5. Sampah bahan berbahaya dan beracun (B3): limbah dari bahan-bahan berbahaya dan beracun seperti limbah rumah sakit, limbah pabrik dan lain-lain. Sementara Alex (2012) lebihmenjelaskan jenis-jenis sampah lebih rinci sebagai berikut:

1 Berdasarkan Sumbernya

a. Sampah alam: sampah yang diproduksi di kehidupan liar diintegrasikan melalui proses daur ulang alami, seperti daun-daun kering di hutan yang terurai menjadi tanah.

b. Sampah manusia: hasil-hasil dari pencernaan manusia, seperti feses dan urin.

c. Sampah rumah tangga: sampah dari kegiatan di dalam rumah tangga, sampah yang dihasilkan oleh kebanyakan rumah tangga adalah kertas dan plastik.

d. Sampah konsumsi: sampah yang dihasilkan oleh manusia dari proses penggunaan barang seperti kulit makanan dan sisa makanan.

e. Sampah perkantoran: sampah yang berasal dari lingkungan

perkantoran dan pusat perbelanjaan seperti sampah organik, kertas, tekstil, plastik dan logam.

f. Sampah industri: sampah yang berasal dari daerah industri yang terdiri dari sampah umum dan limbah berbahaya cair atau padat.

g. $\quad$ Sampah nuklir: sampah yang dihasilkan dari fusi dan fisi nuklir yang menghasilkan uranium dan thorium yang sangat berbahaya bagi lingkungan hidup dan juga manusia.

6. Berdasarkan Jenisnya

a. Sampah organik: buangan sisa makanan misalnya daging, buah, sayuran dan sebagainya.

b. Sampah anorganik: sisa material sintetis seperti plastik, logam, kaca, keramik dan sebagainya.

b Berdasarkan Bentuknya :

Sampah padat: segala bahan

buangan selain kotoran manusia, urin dan sampah cair.

Sampah cair: bahan cairan yang telah digunakan lalu tidak diperlukan kembali dan dibuang ke tempat pembuangan sampah.

\section{Faktor yang Mempengaruhi Jumlah Timbunan Sampah}

Dalam Isa (2010) yang dikutip dari berbagai sumber, faktor-faktor yang mempengaruhi timbunan sampah adalah :

\section{Jenis Bangunan yang Ada}

Jenis bangunan dan luas bangunan 
berpengaruh pada jumlah sampahnya, makin luas suatu bangunan makin banyak timbunan sampahnya.

\section{a. Tingkat Aktivitas}

Jumlah sampah yang timbul pada

setiap bangunan berhubungan langsung dengan tingkat aktivitas yang dilakukan oleh penghuninya, misalnya:

- $\quad$ Bangunan pasar, makin beraneka

ragam barang yang diperdagangkan, makin besar timbunan sampahnya.

- $\quad$ Perkantoran, makin banyak aktivitas yang dilakukan makin banyak timbunan sampahnya.

- Industri, makin besar kapasitas produksinya (aktivitas tinggi),

makin banyak timbunan sampahnya

3. Jumlah dan Kepadatan Penduduk Pertambahan jumlah sampah

secara teoritis akan bertambah sesuai dengan pertambahan jumlah penduduk dan aktivitas yang dilakukannya. Makin banyak jumlah penduduk suatu daerah, makin banyak pula timbunan sampah yang dihasilkan. Demikian pula dengan tingkat kepadatan penduduknya, makin padat penduduk yang tinggal disuatu

daerah, makin banyak timbunan sampahnya karena tidak ada tempat atau ruang yang dapat menyerap sampah secara on-site.

\section{Sosial Ekonomi dan Budaya}

Makin tinggi tingkat ekonomi suatu daerah, maka laju konsumtivisme masyarakatnya pun meningkat membuat laju timbunan sampah meningkat.

Demikian pula dengan budaya masyarakat setempat akan berpengaruh pada timbunan sampahnya.

\section{Kondisi Geografi}

Timbunan sampah di daerah pegunungan berbeda dengan timbunan sampah di daerah pantai. Daerah pegunungan yang pada umumnya didominasi oleh pertanian/perkebunan, timbunan sampahnya lebih tinggi dibandingkan dengan daerah lainnya

\section{Dampak TPAS terhadap Sosial Ekonomi Masyarakat Sekitar}

Adanya Tempat Pembuangan Akhir Sampah (TPAS) di suatu daerah

akan membawa pengaruh bagi masyarakat maupun lingkungan daerah itu sendiri. Pengaruhnya tentu saja ada yang positif dan ada juga yang negatif.

\section{Pengaruh Positif}

Pengelolaan sampah yang baik akan memberikan pengaruh yang positif terhadap masyarakat maupun lingkungannya, seperti berikut :

a. Sampah dapat dimanfaatkan untuk menimbun lahan semacam rawa-rawa dan dataran rendah.

b. Sampah dapat dimanfaatkan sebagai pupuk.

c. Sampah dapat diberikan untuk makanan ternak setelah menjalani proses pengelolaan yang telah ditentukan lebih dahulu untuk mencegah pengaruh buruk sampah tersebut terhadap ternak. 
d. Pengelolaansampah

menyebabkan berkurangnya tempat untuk berkembang biak serangga dan binatang pengerat.

e. Menurunkan insiden kasus penyakit menular yang erat hubungannya dengan sampah.

f. Keadaan estetika lingkungan yang bersih menimbulkan kegairahan hidup masyarakat.

g. Keadaan lingkungan yang baik mencerminkan kemajuaan budaya masyarakat.

h. Keadaan lingkungan yang baik akan menghemat pengeluaran dana kesehatan suatu negara sehingga dana itu dapat digunakan untuk keperluan lain.

\section{Pengaruh Negatif}

Pengelolaan sampah yang kurang baik dapat memberikan pengaruh negatif bagi kesehatan, lingkungan, maupun bagi kehidupan sosial ekonomi dan budaya masyarakat, seperti berikut.:

a. Pengaruh terhadap kesehatan

1) Pengelolaan sampah yang kurang baik akan menjadikan sampah sebagai tempat perkembangbiakan sumber penyakit, seperti lalat, tikus, serangga, jamur.

2) Penyakit demam berdarah semakin meningkat, disebabkan vektor Aedes Aegypty yang hidupberkembang biak di lingkungan yang pengelolaan sampahnya kurang baik (banyak kaleng, ban bekas dan plastik dengan genangan air).

3) Penyakit sesak nafas dan penyakit mata disebabkan bau sampah yang menyengat yang mengandung Amonia Hydrogen, Solfide dan Metylmercaptan.

4) Penyakit saluran pencernaan (diare, kolera dan typus) disebabkan banyaknya lalat yang hidup berkembang biak di sekitar lingkungan tempat penumpukan sampah.

5) Insidensi penyakit kulit meningkat karena penyebab penyakitnya hidup dan berkembang biak di tempatpembuangandanpengumpulan sampah yang kurang baik. Penularan penyakit ini dapat melalui kontak langsung ataupun melalui udara.

6) Penyakit kecacingan.Terjadi kecelakaan akibatpembuangan sampah secara sembarangan misalnya luka akibat benda tajam seperti kaca, besi.

7) Gangguan psikomatis, misalnya insomnia dan stress

b. Pengaruh terhadap lingkungan

1) Pengelolaan sampah yang kurang baik menyebabkan estetika lingkungan menjadi

kurang sedapdipandangmatamisalnyabanyaknya tebaran-tebaran sampah sehingga mengganggukesegaran udara lingkungan masyarakat.

2) Pembuangan sampah ke dalam saluran pembuangan air akan menyebabkan aliran air akan terganggu dan saluran air akan menjadi dangkal.

3) Proses pembusukan sampah olehmikroorganisme akan menghasilkan gas-gas tertentu yang menimbulkan bau busuk.

4) Adanya asam organik dalam air serta kemungkinan terjadinya banjir maka akan cepat terjadinya pengerusakan fasilitas pelayanan masyarakat antara lain jalan, jembatan, saluran air, fasilitas jaringan.

5) Pembakaran sampah dapat menimbulkan pencemaran udara dan bahaya kebakaran lebih luas.

6) Apabila musim hujan datang, sampah yeng menumpuk dapat menyebabkan banjir dan mengakibatkan pencemaran pada sumber air permukaan atau sumur dangkal. 
7) Air banjir dapat mengakibatkan kerusakanpadafasilitasmasyarakat, seperti jalan, jembatan, dan saluran air.

c. Pengaruh terhadap sosial ekonomi dan budaya masyarakat

1) Pengelolaan sampah yang kurang baik mencerminkan keadaan sosial-budaya masyarakat setempat.

2) Keadaan lingkungan yang kurang baik dan jorok, akan menurunkan minat dan hasrat orang lain (turis) untuk datang berkunjung ke daerah tersebut.

3) Dapat menyebabkan terjadinya perselisihan antara penduduk setempat dan pihak pengelola

4) Angka kesakitan meningkat dan mengurangi hari kerja sehigga produktifitas masyarakat menurun.

5) Kegiatan perbaikan lingkungan yang rusak memerlukan dana yang besar sehingga dana untuk sektor lain berkurang.

6) Penurunan pemasukan daerah (devisa) akibat penurunan jumlah wisatawan yang diikuti denganpenurunan penghasilan masyarakat setempat.

7) Penurunan mutu dan sumber daya alam sehingga mutu produksi menurun dan tidak memiliki nilai ekonomis.

8) Penumpukan sampah di pinggir jalan menyebabkan kemacetan lalu lintas yang dapat menghambat kegiatan transportasi barang dan jasa.

\section{Metodologi Penelitian \\ Metode Penelitian}

Metode yang digunakan dalam penelitian ini adalah pendekatan kualitatif. Untuk mendukung proses itu digunakan metode wawancara. Teknik yang digunakan ialah dengan mengajukan

pertanyaan-pertanyaan yang sesuai dengan materi yang diteliti (interview) kepada Responden dan Informan.

\section{Responden dan Informan}

Penelitian ini menggunakan Responden dan Informan sebagai sumber informasi. Responden yang ditentukan ialah orang-orang yang berprofesi sebagai petani, pemulung, dan petani sekaligus pemulung, berjumlah 10 orang

Sedangkan informan yang ditemui ialah Kepala Lingkungan dan seseorang yang sudah lama tinggal di situ. Jumlah informan yang ditentukan ialah sebanyak dua (2) orang.

\section{Kerangka Teoritis Penelitian}

Kehadiran TPAS mempengaruhi lingkungan sekitar dan sekaligus profesi masyarakat. Selain itu TPAS juga mempengaruhi keadaan ekonomi, pendidikan, dan kesehatan masyarakat yang ada di sekitarnya. Jika kehadiran TPAS menimbulkan dampak negatif, maka dapat menimbulkan masalah baru yaknikemiskinan,mempengaruhi kesehatan masyarakat, dan mempengaruhi pendidikan anak-anak di lokasi TPAS.

\section{Hasil Penelitian}

\section{Gambaran Lokasi Penelitian}

Lokasi penelitian Tempat pembuangan Akhir Sampah Kotamadya Medan atau lazimnya disingkat dengan TPAS di desa Namo Bintang Kecamatan Pancur Batu Kabupaten Deli Serdang, terletak di sebelah Utara desa Namo Bintang dan mempunyai luas areal sekitar 25 hektare. Jarak dari pemukiman ke areal TPAS ini sekitar 1,5 km dan terletak di pinggir 
jalan arah jalan besar Pancur Batu. Sedangkan jarak dari Kotamadya Medan ke TPAS ini berkisar $17 \mathrm{~km}$.

Jarak dari TPAS dengan pemukiman penduduk \pm 50 meter, dengan demikian bau dari TPAS sangat menyengat dari pemukiman penduduk. Selain itu penduduk setempat juga tidak mendapat sarana air bersih dan listrik

\section{Gambaran Responden dan Informan}

Masyarakat setempat umumnya bermata pencaharian sebagai petani, pemulung, dan petani sekaligus pemulung. Kegiatan responden dalam sehari-harinya adalah orang-orang yang berprofesi sebagai petani, pemulung, dan petani sekaligus pemulung. Yang berprofesi sebagai petani umumnya sebagai petani padi, cokelat dan palawija. Sedangkan yang berprofesi sebagai pemulung sekaligus petani, mereka membagikan waktu mereka untuk secara bergantian bekerja di ladang dan bekerja di TPAS atau sebagai pemulung. Tetapi sangat berbeda dengan petani, mereka lebih tenang untuk bekerja dan tidak berpatokan dengan waktu karena mereka bekerja di tanah mereka sendiri.

\section{Sejarah TPAS Namo Bintang}

Desa Namo Bintang merupakan salah satu desa yang terletak di kecamatan Pancur Batu, Kabupaten Deli Serdang. Desa Namo Bintang yang ada sekarang merupakan penggabungan dari dua desa di sekitarnya, yaitu Desa Rumah

Mbacang/Ujung Jawi dan Desa Sumbringen. Pada tahun 1985 ditetapkan nama ketiga desa ini menjadi Desa Namo Bintang dan kedua desa yang ada di sekitarnya diubah menjadi Dusun I dan Dusun II.

Menurut informasi yang diperoleh dari informan, nama Namo Bintang diambil dari nama sebuah sungai yang mengalir di pinggiran desa. Sungai tersebut mempunyai Namo, yang mana kalau diartikan ke dalam bahasa Indonesia berarti Lubuk. Lubuk tersebut dijadikan tempat pemandian dan pemancingan oleh penduduk yang berada di sekitar lubuk-lubuk tersebut. Menurut cerita orang-orang tua, daerah di sekitar Namo (lubuk) dapat mengeluarkan cahaya terang-benderang seperti bintang dikala bulan purnama, dan inilah cikal bakal diberinya nama desa tersebut menjadi Namo Bintang.

\section{Mata Pencaharian Tetap Penduduk di Sekitar TPAS Namo Bintang}

Berdasarkan hasil penelitian, ditemukan bahwa masyarakat di sekitar TPAS khususnya masyarakat desa NamoBintang, mata pencaharian mereka sebelum berdirinya TPAS adalah petani. Namun setelah desa Namo Bintang berdiri, masyarakat sekitarnya ada yang beralih profesi yakni ada yang berprofesi sebagai pemulung dan ada yang tetap sebagai petani. Alasan mereka yang beralih profesi sebagai pemulung dikarenakan bahwa TPAS tersebut dapat membantu serta menambah penghasilan mereka. Sedangkan mereka yang tetap berprofesi sebagai petani dan tidak mau bekerja sebagai pemulung mempunyai alasan bahwa mereka tidak tahan dengan aroma sampah yang ada di TPAS tersebut. Alasan lain dari mereka yang tidak mau bekerja sebagai pemulung ialah mereka berpendapat bahwa bekerja di ladang lebih memberikan hasil yang memuaskan.

\section{Jumlah Pendapatan Penduduk Sebelum dan Sesudah TPAS}

Pada umumnya masyarakat sekitarTPAS Namo Bintang khususnya para petani, biasanya bekerja sesuai dengan kebutuhan dalam keluarga. Jumlah pendapatan para petani tidak dipengaruhi oleh TPAS Namo Bintang, sebab mereka tidak bekerja sebagai pemulung. Para petani bekerja pada saat-saat tertentu. Maksudnya ialah mereka bekerja sesuai dengan apa yang telah mereka tanam di ladang. Untuk menentukan berapa jam mereka bekerja di ladang, menurut mereka tidak menentu. Mereka biasanya bekerja dari pagi sampai siang 
danmelanjutkannya pada sore hari. Sedangkan masyarakat yang beralih profesi dari petani ke pemulung biasanya mereka bekerja dari pagi sampai sore hari. Bahkan ada pemulung yang sudah mulai bekerja di TPAS dari jam 5.00 WIB-17.00 WIB.

Dengan demikian, jika kita melihat jumlah jam yang dipergunakan para pemulung untuk bekerja, ada yang sesuai dengan jumlah pendapatan setiap bulan. Sedangkan ada yang tidak sesuai dengan pendapatan setiap bulan karena pendapatan yang mereka peroleh sangat minim. Namun bila ditanya pendapat mereka tentang TPAS Namo Bintang tersebut, mereka selalu mengatakan bahwa dengan adanya TPAS Namo Bintang tersebut dapat menambah pendapatan mereka. Hal lain yang yang membuat para pemulung merasa beruntung dengan adanya TPAS Namo Bintang ialah mereka dapat memperoleh sisa-sisa makanan untuk memberi makan hewan peliharaan milik mereka seperti babi.

Banyak pendapat dari para pemulung tentang TPAS Namo Bintang. Ada hal yang sangat menarik ialah ada beberapa pemulung yang mengusulkan agar TPAS Namo Bintang yang telah ada di dekat tempat tinggal mereka tersebut tetap berada di lokasi tersebut atau dengan kata lain mereka mau agar TPAS tersebut di perpanjang masa kontraknya.

Berbicara tentang pengeluaransetiap anggota keluarga sedikit mengalami kesulitan karena menurut pendapat para keluarga, pengeluaran setiap bulan tidak menentu. Mereka sering mengeluarkan uang sesuai dengan kebutuhan hidup setiap hari. Namun secara umum dapat dikatakan bahwa pengeluaran keluarga berkisar Rp. 1.300.000/bulan. Jika ditelusuri secara mendalam tentang pengeluaran setiap anggota keluarga khususnya para pemulung tidak sesuai dengan jumlah pendapatan yang mereka peroleh. Hasil yang mereka peroleh tidak mencukupi untuk membiayai kebutuhan keluarga.

Menurut informan selaku kepala lorong Desa Namo Bintang menandaskan bahwa sejak ia menjabat sebagai kepala desa, ia menemukan beberapa kesulitan yang berkaitan dengan TPAS tersebut. Beliau mencontohkan bahwa anggota masyarakat yang berprofesi sebagai pemulung sulit dikumpulkan untuk mengadakan kerja bakti sosial dalam bidang pemerintahan karena pada umumnya para pemulung tidak mempunyai waktu luang untuk mengikuti kegiatan tersebut. Dengan demikian beliau mengharapkan agar tempat pembuangan sampah tersebut tidak diperpanjang masa kontraknya oleh pemerintah kota.

\section{Pengaruh Positif dan Negatif TPAS NamoBintangTerhadap \\ Masyarakat}

Keberadaan TPAS Namo Bintang mempunyai pengaruh terhadap penduduk di sekitarnya secara khusus Namo Bintang. Adapun pengaruh itu mencakup:

\section{Pendapatan}

Dari hasil penelitian, ditemukan beberapa pendapat dari masyarakat khususnya para pemulung tentang TPAS Namo Bintang. Pada umumnya mereka mengatakan bahwa dengan hadirnya TPAS Namo Bintang sangat membantu kehidupan mereka. Pendapatan keluarga atau ekonomi mereka semakin bertambah. Selanjutnya mereka menandaskan bahwa dengan hadirnya TPAS Namo Bintang, masyarakat yang mau bekerja sebagai pemulung mudah mendapatkan uang setiap hari. Dengan demikian mereka dapat memenuhi kebutuhan hidup mereka setiap hari. Hal positif lain yang dikemukakan masyarakat ialah melalui TPAS mereka bisa mendapat sisa-sisa makan sehingga melalui sisa-sisa makanan tersebut mereka dapat beternak babi. Sedangkan bagi masyarakat yang berprofesi sebagai petani sekaligus pemulungTPAS tersebutsangat memberikan peningkatan dalam pendapatan mereka, karena pendapatan keluarga semakin bertambah selain dari ladang ada juga dari TPAS tersebut. Pada umumnya masyarakat Namo 
Bintang mengatakan bahwa dengan hadirnya TPAS di lokasi sekitar pemukiman mereka sangat memberikan peningkatan pendapatan.

\section{Kesehatan}

TPAS Namo Bintang membawa pengaruh negatif yang sangat besar bagi kehidupan masyarakat di sekitarnya terutama desa Namo Bintang. Menurut hasil penelitian, masyarakat sekitarnya sangat mengeluh dengan keberadaan TPAS tersebut. Mereka mempunyai keluhan bahwa TPAS sangat memberikan efek yang besar bagi anak-anak mereka. Pada umumnya bau yang berasal dari TPAS membuat anak-anak mual bahkan yang lebih mengerikan lagi anakanak mereka mendapat penyakit kulit seperti kudis dan juga bau yang datang dari TPAS tersebut membuat masyarakat tidak mempunyai selera makan. Bahkan jika pada musim hujan, banyak lalat yang bertebaran di sekitar lingkungan. Para pemulung pada awal bekerja di TPAS tidak mengalami penyakit, kesehatan mereka baik-baik saja. Namun menurut salah seorang informan yaitu bapak Pakpahan selaku Kepling menandaskan bahwa berdasarkan fakta yang terjadi, orang-orang yang berprofesi sebagai pemulung jika pada suatu saat menderita sakit maka penyakit yang dialami oleh pemulung itu akan sangat parah sehingga tidak tertolong/ tidak bisa diobati oleh dokter.

\section{Pendidikan Anak}

Dari hasil penelitian di TPAS Namo Bintang, masyarakat rata-rata sudah berkeluarga dan memiliki anak lebih dari satu orang. Jika kita melihat pendidikan anak, rata-rata anak mereka bersekolah. Bahkan ada yang berpendidikan hingga SLTA. Pendidikan anak-anak para pemulung sangat dipengaruhi oleh ekonomi keluarga. Meskipun pendapatan para pemulung rata-rata pas-pasan atau di bawah standar UMR namun pendidikan anak hampir sama dengan pendidikan anak para petani yang bisa dikatakan memiliki pendapatan yang cukup besar.

Sedangkan hal negatif dari keberadaan TPAS Namo Bintang terhadap pendidikan anak ialah kurangnya situasi yang mendukung karena anak-anak dari masyarakat desa Namo Bintang tidak memiliki tempat bermain yang sehat bila dibandingkan dengan anak-anak lain. Artinya bahwa kehidupan anak tidak didukung oleh lingkungan yang sehat. Dengan demikian kesehatan anak akan jauh berbeda dengan anakanak yang lain yang jauh dari tempat pembuangan sampah tersebut. Selain itu cara hidup yang berhubungan dengan kebersihan dalam diri anak tidak tertanam dengan baik, hal ini terlihat dari anak-anak sekitar TPAS berpenampilan tidak rapi dan tidak bersih melainkan terlihat kumal dan pucat. Oleh karena itu, dapat dikatakan bahwa pengaruh TPAS terhadap pendidikan anak boleh dikatakan belum memadai secara efisien.

\section{Pembahasan}

Kehadiran TPAS Namo Bintang secara umum tidak memberikan dampak yang lebih positif terhadap penduduk disekitarnya, bahkan cenderung memberikan dampak yang lebih negatif misalnya para pemulung memiliki pendapatan yang begitu rendah bila dibandingkan dengan UMR. Bila hal ini dikaitkan dengan keadaan lingkungan, kondisi lingkungan di TPAS Namo Bintang tidak sehat, ini mengakibatkan masyarakat sering terkena penyakit kulit (kudis, dan gatal-gatal bagi anak-anak). Bila sudah terkena penyakit, maka pendapatan yang mereka peroleh tidak mencukupi untuk menutupi biaya pengobatan yang begitu mahal saat ini.

Kesehatan merupakan faktor yang paling utama dalam kehidupan manusia. Dengan hidup sehat manusia dapat melakukan segala aktifitasnya dengan baik. Demikian sebaliknya, 
manusia yang tidak sehat dapat terganggu aktifitasnya. Misalnya situasi yang kotor kurang memberikan semangat untuk melakukan kegiatan sehari-hari. Demikian pula pengaruhnya bagi anak-anak. Tumpukan sampah yang begitu luas berpengaruh terhadap keleluasaan anak-anak untuk bermain, karena tempat bermain yang terbatas oleh tumpukkan sampah.

Ketidak-merataan pendapatan juga berpengaruh pada pendidikan anak. Para petani yang memiliki pendapatan lebih besar dari para pemulung dan petani-sekaligus-pemulung, mempunyai peluang yang sedikit besar untuk menyekolahkan anak-anak mereka ke jenjang yang lebih tinggi. Dengan demikian variabel-variabel di atas mempunyai pengaruh antara satu dengan yang lain. Pendapatan yang kecil akan mengganggu keadaan ekonomi suatu rumah tangga. Pendapatan yang kecil juga menyebabkan peluang yang sangat kecil untuk membiayai pendidikan anak ke jenjang pendidikan yang lebih tinggi. Sedangkan lingkungan yang tidak sehatakan berdampak pada kesehatan masyarakat yang tinggal di sekitar TPAS yang kurang sehat. Dan kesehatan sangat perlu bagi pendidikan anak sebab anak yang kurang sehat akan terganggu proses belajarnya.

Dari hasil penelitian ditemukan suatu hal baru yakni kurangnya partisipasi secara aktif dari penduduk yang berprofesi sebagai pemulung. Dikatakan demikian karena para pemulung terlalu terfokus pada pekerjaannya sehingga sangat sulit bagi mereka untuk mengadakan kerja bakti secara bersama di dalam lingkungan tempat tinggal mereka. Akibat dari kurangnya kerjasama dalam hal kerja bakti ini, menimbulkan situasi

lingkungan kemasyarakatan kurang mendukung sebagai tempat tinggal yang layak.

\section{Kesimpulan Dan Saran \\ Kesimpulan}

Dari hasil penelitian terhadap masyarakat Namo Bintang yang hidup di sekitar TPAS

Namo Bintang, dapat disimpulkan bahwa pengaruh dari TPAS terhadap penduduk cenderung ke arah yang lebih negatif. Hal ini antara lain karena dampak berdirinya TPAS di Namo Bintang ini menimbulkan gangguan pada kesehatan, pendidikan, dan pendapatan masyarakat sekitar. Dengan pendapatan yang rendah, masyarakat kesulitan untuk memenuhi kebutuhan kehidupan mereka sehari-hari. Pendapatan yang rendah juga menyebabkan peluang yang sangat kecil untuk membiayai pendidikan anak-anak mereka ke jenjang pendidikan yang lebih tinggi. Sedangkan lingkungan yang tidak sehat akan berdampak pada kesehatan masyarakat. Bila sudah terkena penyakit, maka pendapatan yang mereka peroleh tidak mencukupi untuk menutupi biaya pengobatan yang begitu mahal saat ini. Selain dari pada itu, lingkungan yang sehat juga sangat diperlukan bagi pendidikan anak, sebab anak yang kurang sehat akan terganggu proses belajarnya. Bila banyak hal ini terus dibiarkan, maka akan dapat menimbulkan masalah sosial yang baru lagi.

\section{Saran}

Saran yang dapat diberikan antara lain ialah agar pemerintah kota lebih memperhatikan masyarakat yang ada di sekitar TPAS khususnya di desa Namo Bintang terutama menyangkut kesehatan. Selain itu pemerintah juga harus lebih memperhatikan kesejahteraan masyarakat Namo Bintang dan penduduk yang ada di sekitarnya terutama dalam sarana umum seperti air bersih dan listrik yang sampai sekarang belum dinikmati oleh penduduk desa Namo Bintang. Jika dimungkinkan pemerintah kota hendaknya memindahkan TPAS yang jauh dari pemukiman penduduk dengan alasan penduduk yang ada di sekitar TPAS merasa terganggu kesehatannya. Selain itu, penduduk yang ada di sekitarnya menjadi sulit untuk diajak untuk melakukan bakti sosial karena mereka lebih terfokus pada pekerjaan sebagai pemulung yang bekerja dari pagi sampai malam. 


\section{Daftar Pustaka}

Aji, 2008. Sistem Pengelolaan Sampah Terpadu, Artikel Alex S., 2012. Sukses Mengolah Sampah Organik Menjadi Pupuk Organik. Yogyakarta: Pustaka Baru Press

Daniel, Valerina. 2009. Easy Green Living. Bandung: Hikmah

Isa, Meykowati., 2010. Sistem Pengelolaan Sampah di Kota Tilamuta Kabupaten Boalemo Propinsi Gorontalo, Tesis Semarang Universitas Diponegoro

Kodoatie, R.J., 2003. Manajemen dan Rekayasa Infrastruktur, Yogyakarta: Pustaka

Pelajar

Dwiyatmo,Kus., 2007. Pencemaran Lingkungan dan Penanganannya. Yogyakarta: PT Intan Sejati.

Nugraha,2007. Studi Potensi Pemanfaatan Nilai Ekonomi Sampah Anorganik Melalui Konsep Daur Ulang Dalam Rangka Optimalisasi Pengelolaan Sampah (Studi Kasus : Kota Magelang). Vol. 28 No. 1 Tahun 2007, ISSN 0852-1697

Nugroho,2009. Pengelolaan Sampah Secara Terpadu di Padukuhan Kelor Bangunkerto Turi Sleman Yogyakarta, Artikel

Santoso,2009. Penanganan Sampah untuk Menuju Kota Bersih dan Sehat, Artikel

Sukir, 2010. Analisis Pemanfaatan Pengolahan Sampah Organik Menjadi Pupuk Kompos. Universitas Sumatera Utara

Yanti. 2012. Pengembangan Pariwisata Melalui Pengelolaan Sampah Berbudaya. 